\title{
Preparation for transplanting humans and planting vines
}

\author{
Shaun McCann $\mathbb{1}^{1}$
}

Received: 19 October 2020 / Revised: 27 October 2020 / Accepted: 2 November 2020 / Published online: 21 November 2020

(c) The Author(s), under exclusive licence to Springer Nature Limited 2020

'Vines love an open hill'.

Publicus Vergilius Maro (Virgil), Roman poet. 70-19 BC (Fig. 1).

Before embarking on a haemopoietic cell transplant (HCT) programme the selection of patients must be undertaken. When initiating a new program, it is important to make sure the procedure works in order to persuade the institution, government or funding organization that HCT is worth supporting. As time goes on and confidence of staff is gained the selection of patients widens and consideration is given to offer HCT to patients considered high-risk or who have diseases for which HCT is debatable as an appropriate therapeutic strategy.

Radiation has a paradoxical effect: on one hand it causes leukaemia and on the other it is commonly used in so-called myeloablative conditioning regimens prior to HCT. Initially administered as single fraction (12 Gy) [1] with cyclophosphamide, it is now commonly given as fractionated (12 Gy in six doses twice daily or a single fraction daily over 3-4 days) to limit toxicity although cataract formation can occur with single or fractionated radiation [2]. To avoid radiation a stem cell 'poison', busulfan, has been used and was championed by Santos et al. [3]. Originally used for conditioning for myeloid leukaemias it can be used in preparative regimens for lymphoid malignancies [4] and indeed the first patient I transplanted for acute lymphoblastic leukaemia (ALL) in 1984 was conditioned with busulfan/cyclophosphamide and successfully engrafted.

Since the mid-1970s conditioning therapy has changed, notably, with the introduction of reduced intensity

Shaun McCann

shaunrmccann@gmail.com

1 University of Dublin Trinity College, Haematology Emeritus, Dublin, Dublin, Ireland conditioning (RIC) designed to provide sufficient immunosuppression to facilitate engraftment and to allow the induction of the graft versus leukaemia effect [5], and haploidentical HCT. RIC was introduced to reduce the toxicity of myeloablative conditioning and thereby make HCT available to older patients and those with comorbidities and haploidentical HCT to widen the pool of prospective donors. There has never been a head-to-head comparison between RIC and myeloablative conditioning, however, a trial is now under way [6].

In 1998 the observation that the inclusion of radiation in preparative regimens for HCT for severe aplastic anaemia (SAA) resulted in an increase in secondary malignancies [7], thus the omission of radiation for patients undergoing HCT for SAA.

Since the 1970s-1980s busulfan can be given I.V. and plasma levels measured, making its use more acceptable, and other regimens have been introduced using treosulfan, thiotepa, clofarabine and melphalan with cyclophosphamide and of course antithymosyte globulin and Campath (anti CD52 humanised MoAb). Other approaches have utilized BCNU or bendamustine and anti-CD20 radiolabelled MoAb such as yttrium-90-ibritumomab tiuxetan (Zevalin). For a detailed discussion of conditioning regimens see EBMT handbook [8].

Of course, good nursing care, appropriate and rapid administration of antibiotics and anti-fungals, total parenteral nutrition and platelet transfusions on demand have made HCT a safer therapy.

The use of chimaeric antigen receptor $\mathrm{T}$ cells which have been engineered to produce an artificial T-cell receptor cells (CAR-T Cells) shows promise in the treatment of refractory ALL and may be of benefit in the treatment of acute and chronic myeloid leukaemias and multiple myeloma. CAR-T cells may be added to conditioning therapy in so-called high-risk malignancies and although acute toxicity has been managed the long-term success of this approach awaits further clinical trials.

As HCT can be used to treat a variety of malignant and non-malignant haematologic disorders, grapes can be used 


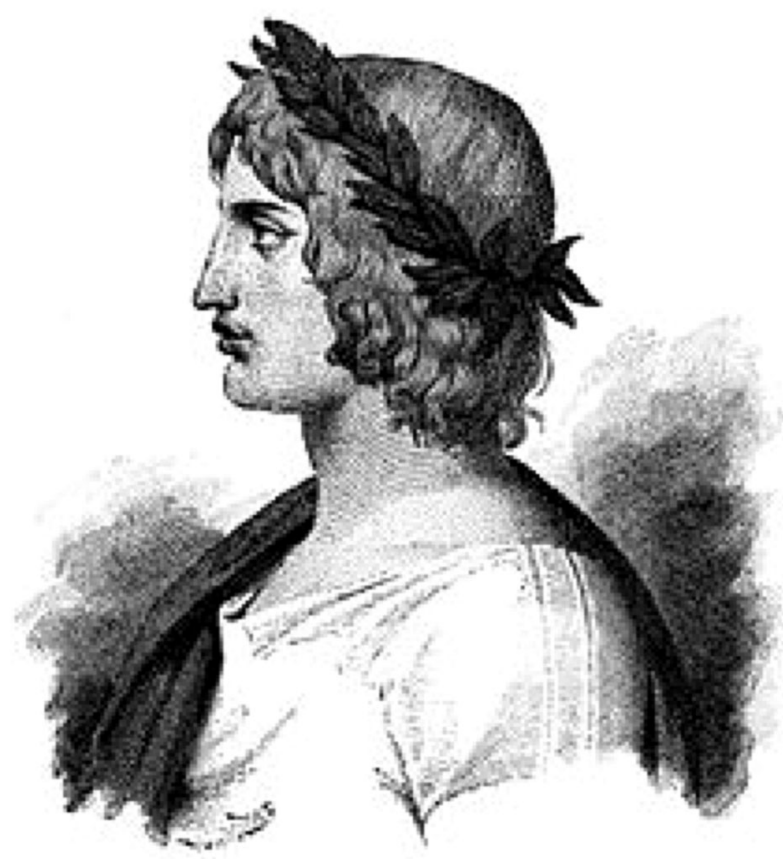

Fig. 1 Virgil. A Roman poet who wrote a lot about viticulture.

for making wine, raisins, jams, and for eating, fresh off the vine. Are there any similarities between setting up an HCT unit and planting a vineyard? Yes. The first thing a wine farmer has to do is to choose an appropriate site. In general, sloping ground, south facing is chosen, and adequate drainage is required. Plentiful sunshine is preferred for most vines and many famous vineyards are found close to rivers.

The type of soil is very important and may determine the type of vine planted. The French refer to the soil characteristics as 'terroir', a difficult term to define but probably means a piece of land defined by the soil, microclimate, topography and cultivation method.

Having established a site and 'terroir' the farmer must decide which vine to plant. Old attitudes are breaking down and grape varieties which we associated with certain regions are now planted world-wide. As we said before most vitis vinifera vines are hermaphrodites so are self-pollinating. Most vines will spend their first 3-4 years producing roots and a sturdy stalk and rarely produce grapes for winemaking for at least 4 years after planting (time to engraftment!) and may last for at least 40-50 years. Terroir, however, is highly variable such as the small stones (Galets roulés) found in the Southern Rhône, Fig. 2 and which are now favoured in many wine producing parts of the world to the Dordogne valley where the soil, is predominantly gravel on the left bank and clay and limestone on the right bank.

Vines, like HCT recipients, need support. The Romans grew their vines on trees as a support structure, and this practise persisted in some parts of Italy until fairly recently. Probably the most widely practised type of support for vines

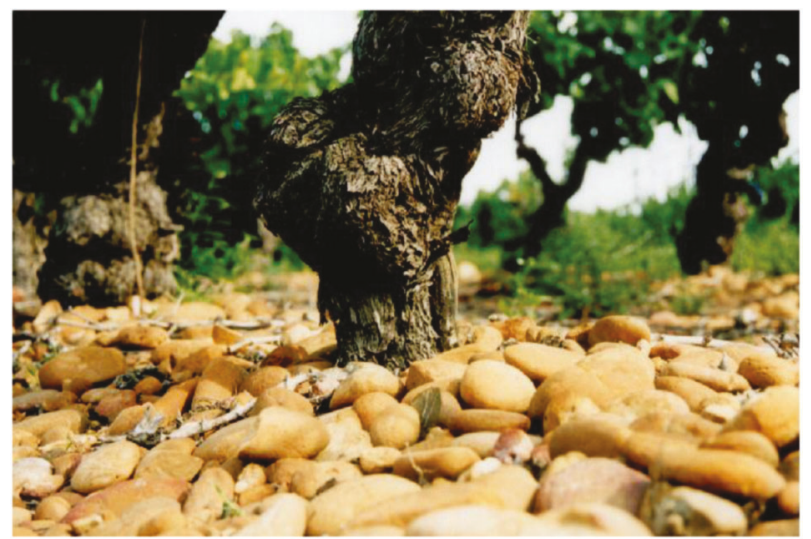

Fig. 2 Galets. Galets are small, flat stones found in the Rhône Valley. They reflect the hot sun and facilitate drainage.

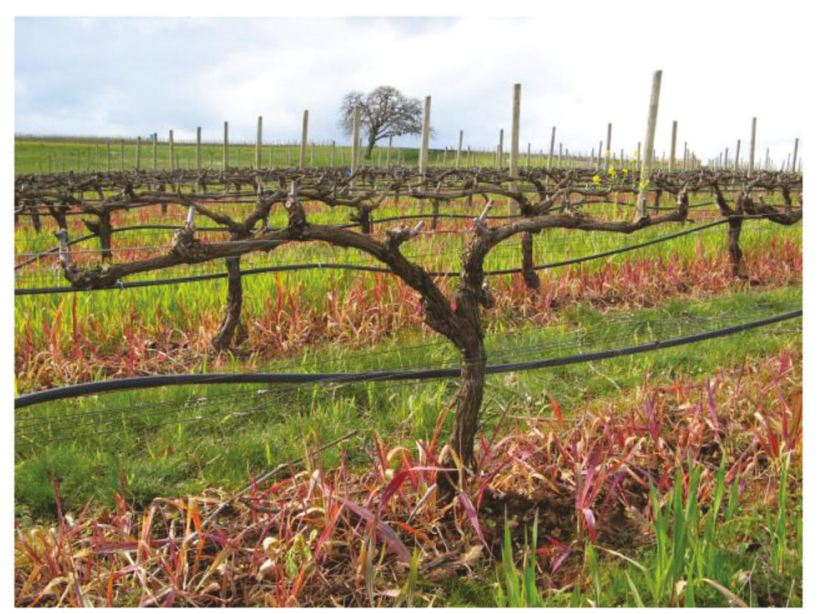

Fig. 3 The Guyot method. The Guyot method is widely used, for training vines, by winemakers.

is the so-called Guyot method (single or double) Fig. 3. In Sicily, South Africa and Australia there was a fashion for cultivating bush vines (free-standing without a trellis system) but nowadays vines are often supported by a trellis system. So, as in HCT many different soils and methods of support are practised (many different conditioning regimens for HCT and many different supports, from laminar flow to positive pressure, HEPA filtered rooms).

Like the transplanter, the wine maker worries about diseases. We have mentioned bacterial, fungal and viral infections in previous 'editorials' and these all cause problems in HCT and wine making.

The Romans used slaves to pick grapes and we know that migrant workers are often poorly paid and the work is often described as back-breaking. The current pandemic is having an impact on grape harvesting [9] and in some instances wine is being turned into hand sanitizer! I'm not sure my nursing colleagues would ever describe looking after HCT recipients as 'back-breaking' but it is hard work. 
So, whether you are initiating an HCT unit or beginning to plant vines you may have similar decisions to make.

\section{Compliance with ethical standards}

Conflict of interest The author declares that he has no conflict of interest.

Publisher's note Springer Nature remains neutral with regard to jurisdictional claims in published maps and institutional affiliations.

\section{References}

1. Thomas ED, Clift RA, Hersman J, Sanders J, Stewart P, Buckner $\mathrm{CD}$, et al. Marrow transplantation for acute non-lymphoblastic leukemia in first remission using fractionated or single-dose irradiation. Int Radiat Oncol Biol Phys. 1982;8:817-21.

2. McCann SR. Cataracts and wine. Bone Marrow Transplant. 2019. https://doi.org/10.1038/s41409-019-0433-4.
3. Santos GW, Tutschka PJ, Brookmeyer R, et al. Marrow transplantation for acute nonlymphocytic leukemia after treatment with busulfan and cyclophosphamide. N Engl J Med. 1983;309:1347-53.

4. Tutschka PJ, Copelan EA, Klein JP. Bone marrow transplantation for leukaemia following a new busulfan and cyclophosphamide regimen. Blood. 1987;705:1382-8.

5. Slavin S, Nagler A, Naparstek E, Kapelushnik Y, Aker M, Cividalli $\mathrm{G}$, et al. Nonmyeloablative stem cell transplantation and cell therapy as an alternative to conventional bone marrow transplantation with lethal cytoreduction for the treatment of malignant and nonmalignant hematologic disease. Blood. 1998;91:756-63.

6. Scott BL, Pasquini MC, Logan BR, Wu J, Devine SM, Porter DL, et al. Myeloablative versus Reduced-Intensity Hematopoietic Cell Transplantation for Acute Myeloid Leukemia and Myelodysplastic Syndromes. J Clin Oncol. 2017;35:1154-61. https://doi.org/10. 1200/JCO.2016.70.7091. Epub 2017 Feb 13. PMID: 28380315; PMCID: PMC5455603.

7. Deeg HJ, Socie G. Malignancies after haematopoietic stem cell transplantation. Blood. 1998;91:1833-44.

8. Nagler A, Shimoni A. Conditioning. In: Carreras E et al., editors. The EBMT handbook. Switzerland: Springer Open, 2019.

9. McCann SR. COVID-19, HCT and wine. Bone Marrow Transplant. 2020. https://doi.org/10.1038/s41409-020-0932-3. 